\title{
Ecology of a Mountain: First Report on Liberian Nimba
}

\section{By Malcolm Coe and Kai Curry-Lindahl}

An isolated mountain range, 40 kilometres long, in the rain forest of tropical West Africa, Mount Nimba lies at the meeting point of three countries: Liberia, Guinea and the Ivory Coast, the last two both former French territories. In 1942 the French initiated ecological research on their parts of the mountain, discovered its extraordinary interest and the very high number of endemic species, and declared a strict nature reserve. Of the Liberian part nothing was known until the discovery of high-grade iron ore in 1955, and the immediate formation of a company to mine it, led the International Union for Conservation of Nature to start an ecological study there. The authors of this report are respectively the first Director of the research unit which, aided by a grant from the mining company, began work in August 1964, and the chairman of the IUCN Mount Nimba Committee.

$I^{N}$ the rain forest region of tropical West Africa are several isolated mountains, most of them under $1,500 \mathrm{~m}$., separated from one another by lowland forests and savannas. The highest, Mount Cameroon on the coast, is $4,070 \mathrm{~m}$., the neighbouring Fernando Po Island rises to $2,850 \mathrm{~m}$., and the Loma massif in Sierra Leone reaches almost $2,000 \mathrm{~m}$. After these comes Nimba, some 170 miles from the Atlantic coast on the borders of Liberia, Guinea and the Ivory Coast; its highest point is $1,752 \mathrm{~m}$. Mount Nimba is a range about $40 \mathrm{~km}$. long, with a general orientation SW-NE, and a maximum width (in Guinea) of about $12 \mathrm{~km}$. The southern end in Liberia gradually drops and narrows, giving the impression from the air of gradually diving down into the lowland forest canopy. Both slopes of this long ridge are steep and abrupt, mostly forest-covered, but with savannas on the highest parts extending down the slopes and some isolated patches of grassland in the forest.

The isolated situation of Mount Nimba gives it the character of a great Inselberg, with types of habitats quite different from the surrounding lowland forests and savannas, and an astonishingly high number of endemics almost entirely on a specific level. This is particularly the case for the animals, of which about 200 endemic species are known. The number will presumably be reduced when the surrounding lowlands and other isolated mountains in West Africa bave been explored, although further explorations at Nimba will certainly yield still more biological surprises. At present it is difficult to say whether the high number of endemic species is due to the fact that Mount Nimba has functioned as a refuge for animals, which during previous pluvial periods were more widely distributed than today, or 
whether these animals, through geographical isolation, have evolved from their ancestral forms into local races and species. Probably both factors have played a part. But even if most of the endemics are relics, Mount Nimba is very important for speciation studies and it can be regarded as a key area for evolutionary research.

The origin of the savannas of Mount Nimba has been much discussed. Many people consider them to be remnants of man's activities: burning, clearing and grazing by livestock. This sounds plausible until one studies the ground. Some features of these grasslands, consisting mainly of Andropogon and Loudetia, seem to indicate that many at least are old natural savannas, which probably correspond to a vegetational climax. They give the impression of being an ancient type of habitat, and a great number of animal species are found there which do not occur elsewhere.

Since 1942 French scientists have carried out intensive investigations on the parts of Mount Nimba in the former French territories of Guinea and the Ivory Coast. In 1944 the French colonial government established a strict nature reserve, La Réserve Naturelle Intégrale du Mont Nimba, covering 48,750 acres and overlapping the boundaries of Guinea and the Ivory Coast, and a laboratory was built by the Institut Français d'Afrique Noire (IFAN) at the foot of the northeastern end of the mountain chain. The results of these valuable scientific explorations, which have been published in Dakar by IFAN, in an impressive series of monographs, emphasised the uniqueness of Nimba and its high scientific importance, and since Guinea and the Ivory Coast became independent UNESCO and IUCN have given both moral and financial support to the reserve and the laboratory. In recent years, however, the laboratory has had no permanent scientific staff, activities there have decreased and the future of the reserve itself seems uncertain.

\section{Mining Provokes Action}

The situation in the Liberian part of the Mount Nimba range was in striking contrast to this intense study and exploration of the former French territories. Virtually nothing was known of the fauna and flora of the Liberian side of the mountain when, in 1955, deposits of high-grade iron ore were discovered in Liberian Nimba. The discovery soon led to preparations for the exploitation of the ore by an international syndicate, LAMCO (Liberian-American-Swedish Minerals Company), and in 1963 mining operations began to destroy the mountain's hitherto virgin state. The Executive Board of IUCN felt that it was urgent to make botanical, zoological and ecological studies to preserve a record of the undisturbed Liberian side of Nimba.

The Directors of the Grängesburg Company, and particularly its Managing Director, Mr. Erland Waldenström, and LAMCO were approached in Stockholm and Liberia. The Executive Board of LAMCO made a grant of $\$ 50,000$ for the first two years biological research, and IUCN appointed the Nimba Research Committee: Kai Curry-Lindahl, chairman, Professor Maxime Lamotte and Professor 
Theodore Monod-to be responsible for liaison with LAMCO as well as for the organisation and supervision of the scientific work and its financial administration. Professor Lamotte has 13 years of field experience of Nimba and Professor Monod has directed the French research work at Nimba since its inception.

In October 1963 Curry-Lindahl went to Liberia to introduce the research project to the Government-the President, the State Department, the Departments of Agriculture and Education-and discuss its operations with various governmental agencies and the University of Liberia. Members of the Cabinet were interested in the suggestion for establishing a reserve at Nimba, and he was asked to submit a detailed plan to the Government. A programme of research for the initial phase was drawn up:

Inventories of the plants and vertebrates.

Zonation of the vegetation and vertebrates (terrestrial and limnic). Ecology of vertebrates. Adaptation of tropical small mammals, reptiles and amphibians to a temperate montane climate.

Seasonal and annual cycles of animal populations.

Effects of elevation and montane climate on vegetable and animal biomasses.

Climatic, hydrological, pedological, botanical and zoological modifications caused by the mining exploitation and operations.

\section{Ecological Research Begins}

On August 1st, 1964, the first team of scientists started work. In charge was Malcolm Coe, of the University College of Nairobi, Kenya, who was also responsible for the zoological investigations; Peter Adames, formerly with FAO and the British Colonial Service, was in charge of the botanical side, to be succeeded later by Dr. F. G. Adam, director of the Botanical Department of IFAN and the University of Dakar. They were joined for a short period by the Dutch zoologist, Dr. A. Kortlandt, of the University of Amsterdam. Their laboratory was a recently vacated hospital at LAMCO's old headquarters camp of Grassfield, and with the company's cooperation and help this was soon equipped with a drying room for plants and skins, an airconditioned laboratory, ample accommodation for stores and for keeping live animals, and with facilities for visiting scientists who, we hope, will work at the station over the next few years. The whole building has now been put at the Committee's disposal and is called the Nimba Research Laboratory. Since November, 1965, Dr. Jacques Verschuren has been head of the Nimba mission.

As the Liberian part of the Nimba massif is continuous with the already well studied Guinea and Ivory Coast parts, it was not expected that much that was new would be found. But a preliminary tour of the region soon showed that the major habitat in the Liberian sector was high forest, with hardly any of the savanna and highland grassland habitats to be found in Guinea. The highest point of Liberian Nimba was $1,300 \mathrm{~m}$., before open-cast mining began, but in little more than 12 
months this had been reduced to under $1,200 \mathrm{~m}$. The main ore deposits, which lie close to the Guinea-Ivory Coast border, are calculated to contain 200 million tons of high-grade ore, and if this is removed as planned at a rate of between 7.5 and 10 million tons a year it will take about 25 years to get down to the lowest deposit at 600 metres. Since Curry-Lindahl's visit to the area in October 1963 the company have cooperated fully in trying to limit their spoil heaps to protect, at least in part, the forest on the mountain's lower slopes, and to date this policy has been very successful. But it is inevitable that, as the mining operations proceed, the forest around the mining area will be largely destroyed. It is fortunate from a conservation point of view that only a small part of the total area of Mount Nimba yields the high grade iron ore and is therefore being exploited at this stage of the company's activities.

\section{Climate}

Since 1957 rainfall and temperature data have been recorded at the Geologists' Camp, at the main mine site $\left(7^{\circ} 31^{\prime} \mathrm{N}, 8^{\circ} 31^{\prime} \mathrm{W}\right)$, at an altitude of $1,343 \mathrm{~m}$. Some readings were made at Yekepa, the main Company township, at $550 \mathrm{~m}$. between 1961 and 1963 but were unfortunately discontinued. A new Meteorological Station is being established in the Research Station compound at Grassfield, $500 \mathrm{~m}$. up, in order to build up a more complete climatic picture. The mean annual rainfall recorded at Yekepa $(550 \mathrm{~m}$.) was $1917.7 \mathrm{~mm}$.; at the Geologists Camp site $(1,343 \mathrm{~m}$.) it was $3317.3 \mathrm{~mm}$., almost twice that of Yekepa. Above 850 metres there is not only direct precipitation but dense cloud cover for much of the year, and this must account for even higher precipitation than the rainfall figures indicate. Temperature data for the lower Yekepa site is not available but the average maximum and minimum figures recorded at the Geologists' Camp $\left(1343 \mathrm{~m}\right.$.) range from $30.0^{\circ}$ to $14.0^{\circ} \mathrm{C}$.

\section{Vegetation}

The marked increase in rainfall with altitude is reflected in the zoning of vegetation. The lower slopes of Liberian Nimba consist of mixed rain forest grading at $800-900 \mathrm{~m}$. into Parinari forest. This point of change also marks the cloud line, so that the capping Parinari forest associations may be regarded as "mist" forest. Parinari excelsa, the dominant tree in this vegetation, has its trunk completely covered with a thick layer of filmy ferns, mosses and to a lesser extent lichens. Rain forest between 450 and $850 \mathrm{~m}$. is very mixed but contains a large number of trees of commercial importance which have been exploited by LAMCO for construction purposes. The common genera are Bussea, Chlorophora, Entandophragma, Lophira, Parkia, Piptadenia and Terminalia.

With the introduction of forest roads much shifting rice cultivation is taking place within this forest, and below an altitude of $550 \mathrm{~m}$. much of the high forest habitat is already in an advanced state of 
destruction and degeneration. The Liberian Government, with some foresight, has declared two forest reserves in Eastern and Western Nimba which it is hoped will shortly lead to effective control of agricultural activities. Valley bottoms contain small areas of wet ground that support small stands of Raphia palm, while river courses associated mostly with the Ya River drainage support interesting riverine forests, though their association with high forests does not make it as obvious as the riverine gallery forest described by Schnell ${ }^{5}$ in the savanna below Guinea Nimba. Laterite pans in the forest bear communities of mixed grass species which may be regarded as outliers of the more extensive savanna habitat a few miles away over the Guinea border.

This variety of vegetation habitats provides the major source of interest for ecologists, and one suspects that the habitat segregation that is fairly easy to observe in East Africa will also be shown to exist in these regions of dense and in places almost impenetrable forest.

\section{Research Work and Results}

In its first five months the mission applied itself to the task of obtaining a general picture of the vegetation and its associated vertebrate fauna. Beginning work in early August we were fortunate in being able to observe changes in the forest throughout the heaviest part of the rainy season and into the beginning of the dry season.

Vegetational Studies

Peter Adames, botanist to the mission, collected 460 species during five months by regularly visiting roads and tracks that passed through all the major vegetation types. Undoubtedly some species were missed, but all species of primary importance in vegetation structure that flowered during this period were collected, with notes on their altitude, soil and associations, and rapidly built up an interesting picture of the major vegetation types.

Dr J. G. Adam completed his botanical programme in July, 1965, and has now built up a representative herbarium of the flora, etc., with more than 1000 species. This information should allow a more accurate evaluation to be made of the plant ecology of Liberian Nimba.

In addition to the all-important collecting, $\mathrm{Mr}$ Adiames studied the encroachment of shifting rice cultivation in the high forest. By December, 1964 , it was possible to plot the extent of this on the concession area $1: 20,000$ maps and to show that the area at present unaffected by these activities lies above $550 \mathrm{~m}$. It was also possible to examine the regeneration of forest on old farms, and in areas felled by LAMCO.

\section{Vertebrate Studies}

Fishes. All the streams contributing to the Ya River drainage contained large numbers of small fish. In quite large mixed shoals two species, Barbus trispilus and Haplochilichthys nimbaensis, were common. Feeding among stones in stream bottoms Amphilius grammatophorus was recovered.

Amphibia. The rainy season 1964 provided an excellent opportunity to collect Amphibia, and 70 specimens were preserved together with notes on the colour and habitats of the living animals. Of great interest was the discovery at $1200 \mathrm{~m}$. of a new and interesting locality for the viviparous toad Nectophrynoides occidentalis that had already been found and described in some detail by Guibé and Lamotte ${ }^{2}$ on the summit of Guinea Nimba. The ridge of Liberian Nimba at an altitude of around $1200 \mathrm{~m}$. has been much disturbed by earth-moving activities and in consequence, 
where the forest has been destroyed, the bare ground has quickly been colonised by a dense Melistometum scrub amongst which occur small, steeply eroded iron ore exposures. This mineral weathers as a series of fiakes and it is beneath these that Nectophrynoides has been discovered in Liberia. The only other two species of Nectophrynoides known to science at the present time occur in East Africa, an enormous gap of over 3000 miles. With this fact in mind it is good to know that every effort is to be made to preserve this remarkable, isolated amphibian habitat.

The Foam Frog Chiromantis rufescens was building its nest on Harungana and Musanga trees along track sides over seasonal pools. On one occasion a female was observed constructing her strange "meringue like" nest with the assistance of three males. It is hoped to continue the work on Amphibia during the next rainy season, when an effort will be made to make complete life cycle collections of the main species.

Reptiles. Towards the end of the rains snakes began to come out of the forest and were caught close to the laboratory in Grassfield. The commonest of these were two species of bird-eating tree snakes, Boiga blandingii and $B$. pulverulenta. Thirty specimens were collected, documented and preserved. Since the collection is as yet quite small, detailed study of these creatures is being deferred until more representative collections have been made.

There were surprisingly few lizards in the study area. Both Agama agama and Mabuya blandingii were common in grassfields close to human habitation. Varanus niloticus were found along all the stream courses and on the main Nimba ridge at $700 \mathrm{~m}$. in an old hollow tree. The colourful Lygosoma nimbense was caught in several grassfields where they inhabited the bases of grass tussocks. The chamaeleon Chamaeleo gracilis was common in grass fields and marginal vegetation throughout the area.

Birds. The Liberian Nimba avifauna is greatly in need of further investigation, One hundred and fifty specimens were collected, comprising nearly 70 species. Subjects worthy of further investigation are the presence at Nimba from September to at least December of more than one subspecies of the yellow wagtail, Motacilla flava. The presence of $M$. flava flavissima was reported after a visit by Curry-Lindahl to Nimba in October, $1963^{1}$, but it was impossible to determine the racial identity of the birds observed by the same author in December, 1964.

In September-Ootober, 1964, large colonies of weaver birds were observed breeding in the savanna outliers, which are easily accessible from the research station. Perhaps the most interesting though most difficult study would be an investigation of some of the more secretive forest birds about which so little is known.

Mammals. The main effort in the vertebrate programme was directed towards a study of the mammais, their altitudinal and habitat stratification and the present status of the larger species. Four hundred and seventy specimens were examined and either preserved in alcohol or as skins. The distribution of animals collected amongst the major orders is as follows:

Table 1.

\section{Mammals Collected between August-December 1964}

Order

Insectivora

Chiroptera

Primates

Pholidota

Rodentia

Carnivora

Artiodactyla

TOTAL

No. of Specimens No. of Species

$\begin{array}{lrr}\ldots & 15 & 3 \\ \ldots & 165 & 15 \\ \ldots & 4 & 3 \\ \ldots & 1 & 1 \\ \ldots & 274 & 27 \\ \ldots & 3 & 3 \\ \ldots & 8 & 4 \\ \ldots & 470 & 56\end{array}$

Species numbers are only approximate until all the material has been thoroughly studied. 
As was to be expected rodents formed the larger part of our collections and agree closely with those recorded for Guinea Nimba ${ }^{3}$. Much useful data was obtained with regard to their zonation and movement during and after the rains. A large percentage of the females trapped were breeding.

The bats provided by far the most interesting new information, particularly the Megachiroptera (fruit bats). These were collected in mist nets both in the forest and at selected altitudes along the service road that follows the main Nimba ridge. It was possible to show that there is a distinct migration path of these creatures across saddles on the main ridge. The migration was continuous over the period of netting ( $2 \frac{1}{2}$ months) and marked animals were not recaptured at the same or other trapping stations. Almost all mature females captured in this way were pregnant.

The highlights of these collections were one specimen of the collourful Scotonycteris ophiodon, which has only been recorded once in Liberia previously (four specimens known to science), and $S$. zenkeri that had only been recorded in the Cameroons and Ghana (also only four specimens known to science).

\section{Conservation}

The large influx of people working for LAMCO and in association with the Bapa alluvial diamond fields has led to extensive farming, and also hunting which is almost all done at night with carbide generator head lamps. Small antelopes like Cephalophus dorsalis, $C$. niger, Philantomba maxwelli, Hyemoschus aquaticus and Tragelaphus scriptus still occur in surprisingly large numbers, but if hunting continues at its present rate their status can hardly be maintained for long. Although hunters have been familiar in the past with the bongo Boocercus eurycerus, the forest buffalo Syncerus nanus, Jentink's duiker Cephalophus jentinki, and the pigmy antelope Neotragus pygmaeus, there were no reports of any of these creatures in the concession area during our mission.

One or two groups of chimpanzee Pan troglodytes were located in the main Nimba-South Nimba valley, and there are at present no signs that they are being hunted. Dr. A. Kortlandt visited the area in February 1965 for a special study of the chimpanzee and the following passage is quoted from his report to Curry-Lindahl:

"In the LAMCO concession area of the Nimba Mountains the population density of chimpanzees is definitely low, and very much lower than what might be expected if no human persecution would occur. The French botanist Dr. Adam who was working in the LAMCO concession area and who kindly joined me in the field, heard chimpanzee calls on the average only once in three weeks during the months when he worked there. Our field guide was unable to show me any chimpanzee nests, and he could show only two chimp paths which gave clear evidence that chimpanzees rarely passed there. This is a striking contrast with what I saw and heard in the Nimba Reserve in Guinea in 1960, where chimpanzee tracks were very numerous and the cries could be heard several times per day (particularly at c. $800 \mathrm{~m}$.).

"The cause of the low chimpanzee density in the LAMCO concession area is undoubtedly the intensive hunting by Liberians 
who have come from other regions and who do not belong to the Manon tribe. (The Manon do not eat chimpanzees and are the autochthonous tribe). I found several cartridges in the forest. Moreover, I did not hear any antelope alarm call, contrary to what I found in the Guinean Nimba Reserve in 1960, where I did not manage to approach and watch chimpanzees owing to the frequency of warnings given by antelope."

The establishment by the Liberian Government of a forest reserve at Nimba will, it is hoped, lead to adequate control measures to conserve these unique habitats and their animals.

\section{Acknowledgments}

The authors would like to thank the Liberian Government and the University of Liberia for their cooperation in setting up this important research project. The help of the LAMCO J..V Operating Company is gratefully acknowledged. Without LAMCO's financial and moral support the Nimba Research Laboratory would never have been set up nor the investigations in the field carried out. The Nimba Research Committee of IUCN would particularly like to express its gratitude to Mr. Erland Waldenström, Managing Director of the Grängesberg Company, to Mr. Tryggve Angel, Director of the Liberia Division of the same Company, to Mr. Ake Karlström and Mr. Richard H. Lowe, former and present General Managers of the LAMCO, and to Mr Ake Hagström of the Liberia Division of the Grängesberg Company, who have been of great help. Last but not least we acknowledge the skilful assistance of $\mathrm{Mr}$. Edward Yallah, member of the mission, and his many Mano friends who placed at our disposal their vast knowledge of the flora and fauna of this their home country.

\section{Literature Cited}

1. CURRY-LINDAHL K. (1964). Yellow wagtails, Motacilla flava flavissima, found in great numbers at Mount Nimba, Liberia, Ibis. Vol. 106, No. 2, pp. 255-266.

2. GUIBE, J. and LAMOTTE, M. (1958). XII. Batraciens, Mem. de l'IFAN, No. 53, Fasc. IV, pp. 245-247.

3. HEIM de BALSAC, $H$. and LAMOTTE, M. (1958). XV. Mammifères rongeurs (Muscardinides et Murides), Mem. de l'IFAN. No. 53, Fasc. IV, pp. 339-357. Dakar.

4. LECLERC, J. C., RICHARD-MOLARD, J., LAMOTTE, M., ROUGERIE, G. and PORTERE, R. (1955). La chaîne du Nimba. Essai géographique. Mem. de l'IFAN. No. 43, Fasc. III.

5. SCHINELL, R. (1952). Végétation et flore de la rôgion montagneuse du Nimba. Mem. de l'IFAN. No. 22.

\footnotetext{
A CHEERFUL report from the Albert National Park reaches FPS from A an Oxfam official in the Congo through a member of FPS, Mr David Sorrell: "I have been to Lake Kivu amongst other places. Quite astonishingly the Albert National Park has positively flourished as a result of no tonirists and in spite of the rebels, who fortunately had a 'taboo' against killing wild animals. The result, with an all-Afrioan game department, is that there must be at least 20,000 buffaloes at large-we saw herds of 100-300 all over the place at least 1000 elephant, and no end of hippos and small game." From the neighbouring Queen Elizabeth National Park in Uganda, however, comes the report that rangers manning posts overlooking the Congo border report seeing considerable hunting by poachens in the "ill-patrolled" Albert National Park.
} 